\title{
The Relationship between Organisational Culture and Job Satisfaction in Higher Education Institutions: The Bishkek Case
}

\author{
Celalettin Serinkan ${ }^{1}$, Mehmet Kiziloglu²* \\ ${ }^{1}$ Business Administration, Faculty of Economics and Administrative Sciences, Pamukkale University, Kinikli Campus, \\ 20160 Pamukkale, Denizli, Turkey \\ 2 Business Management, Kale Vocational School, Pamukkale University, Cumhuriyet Mah. İstiklal Bulvarı No. 24, 20570 Kale, \\ Denizli, Turkey \\ *Corresponding author, e-mail: mkiziloglu@pau.edu.tr
}

Received: 21 November 2019, Accepted: 26 October 2020, Published online: 18 February 2021

\begin{abstract}
Organisational culture and job satisfaction are crucial insofar as human resources are the most valuable resources organisations have in today's business world. Organisational culture encompasses the characteristics that unite and integrate employees of an organisation and distinguish them from employees of other institutions. An employee who has high job satisfaction is an employee who enjoys his/her job and is satisfied with the conditions provided by the organisation. By doing the best that they can do, employees with high job satisfaction ensure that the institution has a competitive advantage and, as a result, extends its life. In this study, questions about organisational culture, levels of job satisfaction and factors influencing them were examined in higher education institutions in Bishkek, Kyrgyzstan. Determining the relationship between organisational culture and job satisfaction in higher education institutions was also one of the objectives of this study. In this study, factors influencing organisational culture and job satisfaction in the case of higher education institutions in the service sector were investigated. In line with the research objective, a questionnaire was conducted in order to be able to explain the factors influencing organisational culture and job satisfaction of university employees and describe the relationship that exists, if any, between organisational culture and job satisfaction. Results showed that there is a significant linear and positive correlation between organisational culture and job satisfaction at a level of $47.2 \%$, which corresponded to a medium strength. In this case, an improvement in organisational culture will cause an increase in job satisfaction.
\end{abstract}

\section{Keywords}

service sector, organisational culture, job satisfaction, high institutions, Bishkek

\section{Introduction}

Rapid advances made in transportation and the communication tools of today have caused the business world to adopt a fast pace and become very mobile. Organisational culture has an essential role in the modern business world, where it has become normal for people who have different languages, different worldviews and subcultures to come together to work together. The culture of an organisation has certain characteristics that direct the behaviours and attitudes of its members and integrate and unite them in accordance with organisational goals. Organisational culture has even a more effective role in the service sector, where the use of human resources is intensive. The organised establishment of operating processes within service institutions, the lack of interruption to interemployee communication, and the formation of a conflict-free business life are only possible in the presence of an appropriate organisational culture.

The organisation concept, which has a number of different definitions, can be defined briefly and in general as the arrangements that people make for specific goals, both purposefully and in an intentional manner. There is a strong connection between the concepts of organisation and culture. Just as every person has a personality of their own, consisting of his or her characteristics and character, every organisation has a personality, and it is called "organisational culture". Beliefs, emotions, behaviours and symbols that are characteristic of an organisation together constitute the culture of that organisation (Demirkol and Savaş, 2012:p.260). 
Organisations always aim to improve their employees' job satisfaction in order to make effective use of available resources and to increase employee productivity. Work is an indispensable part of human life, constituting a large proportion of it. Therefore, an employee's satisfaction with his or her work is very important for his or her psychological and physical health. The ability of employees to perform well and work efficiently depends on their ability to be satisfied with their work (Toker, 2007:p.2). It is possible to achieve the results desired by institutions such as high productivity, a low turnover rate and continuity by keeping the job satisfaction of the members of the institution high.

\section{Theoretical background and hypothesis \\ 2.1 Organisational culture}

Organisational culture is an intellectual structure that enables the organisational reality to be seen; namely, it is a paradigm. In this context, organisational culture is an important concept which separates different organisations from one another, gives them identities and gathers the employees within the same group. Organisational culture found a place in the academic literature for the first time in Blake and Mouton's (1964) article, being introduced with the concept of organisational climate. Towards the late 1970's, the first studies on organisational culture began to be done. Examining the concept of culture in organisational sense, Pettigrew (1979) was the first person to emphasise the concept of organisational culture. Pettigrew opines that organisational culture is comprised of cognitive systems that explain the employees' reasons for thinking, making evaluations and making decisions; that culture is a combination of complex values, beliefs and assumptions (Pettigrew, 1979). Robbins (1986) said "I can't identify what organisational culture is, but I know what it is when I see it." At the same time, the organisation's culture has been defined as "the properties shared by the people involved in the organisation and what makes the organisation different from other organisations." Organisational culture is defined by Schein (1990) as "basic assumption patterns that were revealed during the inherent integration and adaptation with the external environment of any community, determined, developed or taught later on, proved to be correct with the positive results given and then needing to be taught as the right way of perceiving problems, thinking and feeling for new members". Denison (1990) defined the organisational culture as fundamental values, beliefs and assumptions that the organisation members accept and are present in the depths of the organisation.
If the majority of the organisation members have the same opinions about mission and values of the organisation, we can say that a strong organisation culture dominates that organisation. However, if the opinions vary, that means that there is a poor culture (Rosenthal and Masarech, 2003). As the organisation which has a strong organisational culture reveals an important togetherness or goal congruence in terms of the values that it represents, labour turnover will decrease. This togetherness, harmony and loyalty will enable organisational devotion and organisational strength to materialise (Robbins and Judge, 2013; Schulte et al., 2009).

Information relating to the organisational culture is given to employees without being written or spoken. The common culture acts as a guide in this way. But people are unaware of culture until culture challenges them or passes on to another culture. This explains why managers and scientists have neglected culture for a long time (Cameron and Quinn, 2005:p.14).

Hofstede et al. (2010) says that organisational culture was the most debated concept in the field of management with the 1980s. In this period, American firms held an important position in the world. Japanese firms, in their role as the biggest rival of American firms, had become decisive in the world economy with a sudden rise (Harrison and Carroll, 2006:p.6). The realisation that this rise stemmed from a robust relationship between the organisation and its members (Morgan, 2006:p.118) made the concept of organisational culture quite important.

Each of the models developed for organisational culture features qualities facilitating an understanding of it. Hence, organisational culture, which has a very complex structure, is becoming more intelligible with the help of such models (Unutkan, 1995:p.67).

\subsection{Job satisfaction}

Job satisfaction is the most widely researched concept among studies on organisational behaviour as it is a key business attitude that is associated with the quality of work in every organisation. Job satisfaction is associated with important organisational variables such as employee attendance, turnover rate and efficiency (Loi et al., 2009:p.770). Since the early 1900s, job satisfaction has become the focus of many studies and has many different definitions today (Handsome, 2009:p.39). Hoppock has defined job satisfaction as "a combination of psychological, physiological and environmental factors that drive the employee to say, "I am satisfied with my job"" (Tanner, 2007:p.25). 
Robbins, on the other hand, has defined it as the degree to which employees love what they do (Çetin, 2011:p.74). Job satisfaction is a function of "values", which are defined as "what a person desires to achieve consciously or unconsciously." The more the "importance of values" is satisfied/ achieved in business life, the higher the job satisfaction (Wagner and Hollenbeck, 2010:p.138).

In the literature, different authors address factors related to job satisfaction under different dimensions. Luthans has listed these dimensions as nature of work, wages, chance of promotion, management and colleagues (Tella et al., 2007:p.5) and Spector has specified them as wages, promotions, managers, additional opportunities, possible rewards, working conditions, colleagues, nature of work, and communication (Yelboğa, 2009:p.1066). A decline in productivity, an increase in willingness to quit one's job, an increase in reluctance to go to work and absenteeism, a desire to get away from work, decreased organisational commitment, an inability to cooperate, an urge to feel inadequate, an increase in hiring costs and costs of training for new employees, and an increase in employee turnover costs all have negative consequences for organisations caused by low job satisfaction (Bayrak Kök, 2006:pp.296-297; Luthans, 1995:pp.128-130; Tanner, 2007:p.29; Udechukwu, 2007).

Although many factors can be listed as affecting the job satisfaction levels of employees, it is possible to collect them together under two groups as individual and organisational factors in the literature (Sabuncuoğlu and Tüz, 2005:p.323). Individual factors are age, gender, marital status, educational level, occupational position and seniority, personality, intelligence, term of office and so on. Organisational factors are classified as the nature of one's work, management style and control style, sense of security, communication, wages, development and promotion opportunities, competition, working conditions, colleagues and organisational environment (Akınc1, 2002:p.6).

Job satisfaction not only improves employee happiness, but also allows employees to connect to work, work efficiently, reduce defective and faulty product rates, and decrease labour turnover rates (Querstein et al., 1992:pp.859-873). Job satisfaction presents a dynamic structure. Managers cannot just ensure job satisfaction and then keep it out of sight for a number of years. Job satisfaction can be achieved quickly but can also turn into job dissatisfaction just as quickly. The most important evidence that conditions in an organisation are going bad is that job satisfaction is low. Job dissatisfaction is present in latent ways behind slowdown strikes, low productivity, disciplinary problems and other organisational problems. Job dissatisfaction weakens an organisation's immune system, and weakens and even demolishes the organisation's response to internal and external threats (Akşit Aşık, 2010:pp.35-36).

As in the production sector, the primary objectives in the service sector are to make a profit and achieve growth and competitive advantage, but such objectives can only be accomplished by achieving customer satisfaction. The process of achieving customer satisfaction means that corporate employees and customers are closely in touch. In this case, the current mood, temper and thoughts of employees providing the service will have a direct bearing on the quality of the service. An institution aiming to achieve success in the service sector must first ensure customer satisfaction. In order to ensure customer satisfaction, it has become imperative that institutions ensure the satisfaction of their employees who will provide the service.

\subsection{Relationship between organisational culture and job satisfaction and research hypothesis}

Human resources are of very high importance in the education sector. Productivity of employees of higher education institutions is improved by their being satisfied with their work and their identifying with the culture of the organisation they work for. Such factors drive them to make more efforts for the future of their institutions. The primary goal of this study was to determine the organisational culture and job satisfaction levels of employees working in the universities in Bishkek. The secondary goal of the study was to identify the factors affecting the organisational culture and job satisfaction of the university staff. The goal was also to investigate whether there was a relationship between organisational culture and job satisfaction.

Organisational culture expresses shared assumptions, values and beliefs, and is the social glue holding an organisation together (Trevino and Nelson, 1999). A strong culture is a system of rules that spells out how people should behave (Deal and Kennedy, 2000). With this approach, the values and norms shared in organisations are thought to have a direct effect on the behaviour and communication patterns of the employees (Tsai, 2011). Strong communication and reduced role uncertainties reduce conflicts in organisations. This situation has also been highlighted as conducive to increased job satisfaction (Türk, 2007:pp.72-103). It is assumed that the process of staff development, training and learning is effective in those organisations where the organisational culture 
is settled. Supporting the individual's development will increase job satisfaction and enable him to connect emotionally with the workplace.

Organisational culture has been researched and analysed as a social phenomenon in both academic and practical fields for a long time in developed countries. However, organisational culture has not been studied with sufficient academic attention in countries such as Kyrgyzstan with an economy in transition, although organisational culture is well-known in terms of certain of its dimensions (Özden and Najimudinova, 2013:p.4815).

An examination of the literature shows that the relationship between job satisfaction and different organisational factors has been investigated. For example, in Odom et al. (1990), as a result of research into organisational culture and job satisfaction in transport organisations, it was revealed that a bureaucratic culture did not increase job satisfaction, but a culture of innovative and supportive organisations positively affected job satisfaction. In Nystrom's (1993) study, it was suggested that in health care organisations, employees working in a strong organisational culture had strong organisational commitment and job satisfaction. Johnson and McIntye (1998) meanwhile investigated the impact of organisational culture on job satisfaction. As a result of their research, it was understood that the organisational culture affects job satisfaction in a positive and meaningful way in all dimensions. It has been determined that the strongest influence of the organisational culture on job satisfaction is in the dimensions of strengthening, participation and recognition. İşcan and Timuroğlu (2007) later researched job satisfaction in the context of different types of organisational culture and found that clan culture and adhocracy culture had a significant and positive correlation with job satisfaction. It was stated in the same study that hierarchy culture and market culture had a significant and negative correlation with job satisfaction (İşcan and Timuroğlu, 2007:p.133). Tsui et al. (2006) declare that most of the research examining the relationship between organisational culture and job satisfaction has found there to be a positive relationship between the two concepts and that organisational culture can increase satisfaction and improve job performance. With a similar approach, Lloyd says that there is a bilateral relationship between job satisfaction and organisational culture, and that as job satisfaction increases, loyalty to the culture of the organisation will increase, and job satisfaction will increase as the organisational culture develops (as cited in Türk, 2007:p.110). Mullins (2010) argues that productivity growth will be achieved if employees are satisfied with their work. Finally, Hakim (2015) found that the organisational culture variables chosen in his research to determine the impact of the organisation's culture on job satisfaction in the banking sector had a direct impact on job satisfaction. The fact that there is a positive relationship between the two concepts in most of the research that examines the relationship between the organisation's culture and job satisfaction supports our research. The relationship between organisational culture and job satisfaction appears to be significant for businesses. Given this context, the hypotheses created for the study are outlined below.

To accomplish the research goal of the study, the hypotheses were determined as follows:

H1: There is a relationship between organisational culture and job satisfaction.

H2: There is a relationship between the dimensions of organisational culture and the dimensions of job satisfaction.

Within the scope of the study, the overall relationship between organisational culture and job satisfaction was analysed. In addition, hypotheses were established in order to analyse the relationships between the dimensions.

\section{Methods}

\subsection{Data and sample}

As of 2017, there are 31 public and 24 private higher education institutions offering undergraduate education in Bishkek, Kyrgyzstan (National Statistical Committee of the Kyrgyz Republic). The population of the study is made up of the staff of 31 public and 24 private higher education institutions operating in Bishkek. Academics working in 12 higher education institutions in Bishkek who agreed to participate in the research constitute the research sample. Taking into account time and cost constraints, the participants were selected based on the convenience sampling method.

The first part of the data set of the study shows the distribution of demographic characteristics of the participants, such as gender, marital status, age and educational status (Table 1).

As shown in Table 1, $59 \%$ (132) of the participants were women. With regard to the marital status of the participants, it is seen that $71 \%$ (159) of the participants were married, and $24 \%$ were single. Considering the ages of the participants, the largest of the distribution groups consisted of university employees who were between 26 and 35 years old, with a rate of $51 \%(115)$. 
Table 1 Demographic findings

\begin{tabular}{|c|c|c|c|c|c|c|c|}
\hline & Variables & Numbers & $\%$ & & Variables & Numbers & $\%$ \\
\hline \multirow{2}{*}{ Gender } & Male & 92 & 41 & \multirow{4}{*}{ Age } & 25 and below & 36 & 16 \\
\hline & Female & 132 & 59 & & $26-35$ & 115 & 51 \\
\hline \multirow{5}{*}{ Education } & Highschool & 18 & 8 & & $36-45$ & 34 & 15 \\
\hline & Undergraduate & 72 & 32 & & $46+$ & 39 & 18 \\
\hline & Master & 58 & 26 & & Married & 159 & 71 \\
\hline & Doctorate & 76 & 34 & Marital Status & Single & 54 & 24 \\
\hline & & & & & Divorced & 11 & 5 \\
\hline Total & & 224 & 100 & Total & & 224 & 100 \\
\hline
\end{tabular}

In the study, there were four categories of educational status. As shown in Table 1, $26 \%$ (58) of the participants had a master's degree, and $32 \%$ (72) of them had a bachelor's degree. Moreover, $34 \%$ (76) of the participants held a PhD degree. This suggests that most of the participants had received higher education. It can be said that this was due to the fact that $69 \%$ of the participants were academic staff.

As shown in Table 2, when the participants were analysed according to the distribution of their jobs in the institution, it was seen that the majority ( $27 \%$ ) were lecturers, and those who marked the option "other" (31\%). The participants who marked the option "other" identified themselves as administrative staff. In addition, $69 \%$ of the participants were found to be academic staff.

Considering the participants' professional experiences, it is seen that the percentage of those who worked 6-10 years $(27 \%)$ was the same as that of those who worked 16 years or more $(27 \%)$. The proportion of employees working for five years or less was found to be $38 \%$. The smallest percentage rate $(8 \%)$ was of the employees who worked between 11 and 15 years. In this table, which explains for how many years the participants had been working in the institution where they worked, it is seen that the employees who had been working for 5 years or more had the highest percentage with a rate of $59 \%$ (133).

Of the university employees, $64 \%$ (144) stated that they chose the education sector voluntarily, $16 \%$ (36) for economic reasons, $13 \%$ (28) for family reasons, and $7 \%$ (16) for other reasons. The participants who chose the option "other" were more likely to describe their decision as a sudden and incidental choice.

\subsection{Data collection tools}

The questionnaire method, which is broadly used in social research, was chosen as the data collection instrument. The questionnaire consisted of three sections. The first section consisted of demographic questions. The second section was about organisational culture, and the organisational culture scale developed by Tsui et al. (2006) was used. There are 24 items and five dimensions on this scale, which was adapted to Turkish by Barutçu and Serinkan (2012). The dimensions are employee orientation, customer focus, innovativeness,

Table 2 Positions, experiences and reasons for job

\begin{tabular}{|c|c|c|c|c|c|c|c|}
\hline & Variables & $N$ & $\%$ & & Variables & $N$ & $\%$ \\
\hline \multirow{6}{*}{ Academic Position } & Prof. & 15 & 7 & \multirow{4}{*}{ Business Experience } & 5 years and less & 86 & 38 \\
\hline & Assoc. Prof. & 38 & 17 & & $6-10$ & 61 & 27 \\
\hline & Assit. Prof. & 23 & 10 & & $11-15$ & 17 & 8 \\
\hline & Research Assitant & 18 & 8 & & $16+$ & 60 & 27 \\
\hline & Lecturer & 61 & 27 & \multirow{6}{*}{$\begin{array}{l}\text { Work Time } \\
\text { at Organisation }\end{array}$} & 5 years and less & 133 & 59 \\
\hline & Others & 69 & 31 & & $6-10$ & 25 & 11 \\
\hline \multirow{4}{*}{ Reason for profession } & Own choice & 144 & 64 & & $11-15$ & 28 & 13 \\
\hline & Family choice & 28 & 13 & & $16+$ & 38 & 17 \\
\hline & Economic choice & 36 & 16 & & & & \\
\hline & Others & 16 & 7 & & & & \\
\hline Total & & 224 & 100 & Total & & 224 & 100 \\
\hline
\end{tabular}


systematic management and control, and social responsibility (Barutçu and Serinkan, 2012). Table 3 shows items of organisational culture.

The last section of the questionnaire was devoted to evaluating job satisfaction. In this context, the job satisfaction scale, which was developed by Spector (1997) and adapted into Turkish by Yelboğa (2009), was used. The scale consists of 36 questions and nine dimensions (Yelboğa, 2009:p.1071). You can see the items of job satisfaction in Table 4.

Eight questions were removed as a result of factor analysis on the job satisfaction scale, and a total of 28 questions and eight dimensions were created. These include wages, promotion, management, prerequisites, working conditions, job itself, colleagues and communication. Some of the questionnaires were conducted face-to-face and some others were left to be filled by the participants in higher education institutions in Bishkek. Of the 380 questionnaire forms that were distributed, 273 were returned. The return rate was calculated to be $72 \%$. After invalid questionnaires containing incorrect and incomplete information were ruled out, a valid set of 224 questionnaires were obtained. The data were classified in the Excel environment and then moved to the SPSS program for statistical analysis.

\section{Results}

In this section of the study, the demographic findings of the participants were presented first. Then, the reliability of the scales and the findings of the scales were analysed. In the last section, statistical analyses regarding the hypotheses were carried out, and a decision on whether to accept or reject the research hypotheses was determined according to the results.

Reliability analysis allows researchers to measure the reliability of a data collection instrument. The reliability coefficient corresponds to a value between 0.00 and +1.00 . The Cronbach's alpha coefficient of the organisational culture scale was calculated to be $\alpha=0.91$. No factor analysis was carried out for the organisational culture scale, and the scale was used as is, with its existing dimensions.

In terms of job satisfaction, the scale used by Spector (1997) was employed. The internal consistency and test-retest reliability coefficients calculated for this scale are 0.91 and 0.71, respectively (Spector, 1997:p.11). The Cronbach Alpha coefficient of the job satisfaction scale used in this study was determined as 0.79 .

Factor analysis was carried out for the job satisfaction scale. First, a Kaiser-Meyer-Olkin (KMO) test and a Bartlett test were carried out to determine whether the data set was suitable for factor analysis. The KMO test is a test for measuring the adequacy of a sample and concerns sample size. The Bartlett test of sphericity tests whether there is a correlation between variables within the main mass, in other words, the integrity of the main mass. A small value resulting from such tests indicates that correlations between variable pairs would not be explained by other variables. The desired KMO value is greater than $60 \%$ (Nakip, 2003:pp.408-409). Accordingly, the KMO value in the $95 \%$ confidence interval was determined as $0.68>0.60$ as a result of factor analysis of the

Table 3 Organisational culture items

Organisational Culture Items

\begin{tabular}{|c|c|}
\hline Employee Orientation & Innovativeness \\
\hline Promoting feeling-sharing among employees & Developing new products and services continuously \\
\hline Emphasizing team building & Ready to accept new changes \\
\hline Encouraging cooperation & Adopting high-tech bravely \\
\hline Trusting in employees & Encouraging innovation \\
\hline Fertilizing cooperative spirit & Systematic Management and Control \\
\hline Concerning for the individual development of employees & Keeping strictly working disciplines \\
\hline Consideration among employees & Having a clear standard on praise and punishment \\
\hline Caring about opinions from employees & Possessing a comprehensive system and regulations \\
\hline Customer Focus & Setting a clarity goals for employees \\
\hline Satisfying the need of customers at the largest scale & Social Responsibility \\
\hline Sincere customer service & Showing social responsibility \\
\hline Customer is number 1 & The mission of the firm is to serve \\
\hline Providing first class service to customers & Emphasizing on economic as well as social profits \\
\hline The profit of customer is emphasized extremely & \\
\hline
\end{tabular}

Source: Tsui et al. (2006) 
Table 4 Rotated factor loadings matrix

\begin{tabular}{|c|c|c|c|c|c|c|c|c|}
\hline \multirow[t]{2}{*}{ 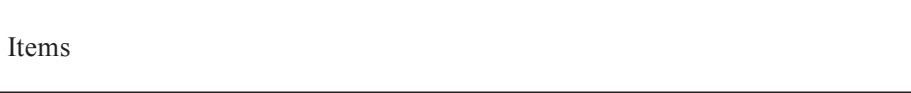 } & & \multicolumn{6}{|c|}{ Factor loadingss } & \\
\hline & 1 & 2 & 3 & 4 & 5 & 6 & 7 & 8 \\
\hline I think I am getting a fair pay for my work. & 0.657 & & & & & & & \\
\hline Increases in wages in my workplace are low & 0.589 & & & & & & & \\
\hline I am happy with the increase in my wages. & 0.704 & & & & & & & \\
\hline $\begin{array}{l}\text { When I think about the wages they are paying me, I feel like I am not being } \\
\text { appreciated. }\end{array}$ & 0.664 & & & & & & & \\
\hline My chances of getting promoted in my work are very low. & & 0.454 & & & & & & \\
\hline Those who do their job well are given a chance to be promoted fairly & & 0.605 & & & & & & \\
\hline People in this workplace get promoted like those in other workplaces. & & 0.456 & & & & & & \\
\hline I think I have a chance to get promoted. & & 0.479 & & & & & & \\
\hline My manager is fair to me. & & & 0.677 & & & & & \\
\hline My manager is very sensitive to the feelings of his/her employees. & & & 0.722 & & & & & \\
\hline I love my managers. & & & 0.756 & & & & & \\
\hline $\begin{array}{l}\text { I am not satisfied with the rights and allowances granted to me in return } \\
\text { for my work. }\end{array}$ & & & & 0.706 & & & & \\
\hline $\begin{array}{l}\text { The rights and allowances granted to me in my workplace are better than those } \\
\text { in many other institutions. }\end{array}$ & & & & 0.655 & & & & \\
\hline The rights and allowances we receive in the workplace are fair. & & & & 0.424 & & & & \\
\hline $\begin{array}{l}\text { There are additional allowances and rights that we are supposed to get but } \\
\text { we do not get them at work. }\end{array}$ & & & & 0.776 & & & & \\
\hline I do not think my efforts are being rewarded as much as they should be. & & & & 0.694 & & & & \\
\hline I am appreciated when I do my job well. & & & & 0.576 & & & & \\
\hline My efforts to do a good job are sometimes hampered by official formalities. & & & & & 0.527 & & & \\
\hline I have to deal with a lot of correspondence and so on in this workplace. & & & & & 0.703 & & & \\
\hline $\begin{array}{l}\text { In the department where I work, the tools that we need are sufficient } \\
\text { (equipment, tools, etc.). }\end{array}$ & & & & & 0.620 & & & \\
\hline I am proud of what I am doing. & & & & & & 0.756 & & \\
\hline $\begin{array}{l}\text { I like the work I do at work. } \\
\text { I have got a lot of work to do at work. }\end{array}$ & & & & & & $\begin{array}{l}0.639 \\
0.710\end{array}$ & & \\
\hline I like the people I work with. & & & & & & & 0.771 & \\
\hline I have to work harder because the people I work with are incompetent. & & & & & & & 0.803 & \\
\hline The objectives of this workplace are clear and evident to me. & & & & & & & & 0.766 \\
\hline There is always open communication in this workplace. & & & & & & & & 0.775 \\
\hline The work I have to do is not clear and lucid enough. & & & & & & & & 0.625 \\
\hline
\end{tabular}

job satisfaction scale, and the result of the Bartlett's tests of sphericity was determined as 1.438 . These results show that the job satisfaction scale was suitable for factor analysis. Varimax rotation was used during factor analysis. Factor loads below 0.40 were not taken into account.

As shown in Table 4, an eight-factor structure describing $64.44 \%$ of the total variance emerged after factor analysis of the job satisfaction scale. These factors were named as follows:

1. Wages,

2. Promotions,

3. Management,
4. Prerequisites,

5. Working conditions,

6. Job itself,

7. Colleagues, and

8. Communication.

A variable indicates a close relationship between the variable and the factor if it has a large loading on that factor. In general, a loading value of 0.60 or above is considered to be high, a loading value between 0.30 and 0.59 is considered as medium, and a loading value of 0.30 or below is considered low (Büyüköztürk, 2002:p.473). 
As shown in the table, the factor loadings were between 0.424 and 0.803 . Therefore, the fact that the lowest factor loading was 0.424 shows that there was not a significant problem in terms of the validity of the structure.

The averages were determined as follows according to the dimensions of the organisational culture and job satisfaction scales, which were administered to the participants during the study (Table 5 and Table 6).

Considering the averages, it is seen that the dimensions of innovativeness $(x=3.30)$ and employee centredness $(x=3.39)$ among the dimensions of organisational culture were the concepts with the lowest overall satisfaction level. The dimensions that had the highest level of satisfaction were found to be student centredness $(x=3.74)$ and systematic management control $(x=3.76)$. The level of organisational culture overall was found to be above the average value. This result shows that participants perceived the development of their institutional culture as moderate. Based on these results, it can be said that the participants thought the dimensions of innovativeness and employee centredness were at a lower level than the other dimensions.

Job satisfaction was categorised under eight dimensions. The averages of the dimensions of job satisfaction are in Table 6.

It was observed that the communication dimension of job satisfaction had the lowest value $(x=2.99)$. The highest

Table 5 Organisational culture dimensions average and standard deviations

\begin{tabular}{lcc}
\hline Dimensions & $\bar{x}$ & SS \\
\hline Employee Centred & 3.39 & 0.7621 \\
Student Centred & 3.74 & 0.8409 \\
Innovativeness & 3.30 & 0.3919 \\
Systematic Management Control & 3.76 & 0.9895 \\
Social Responsibility & 3.63 & 0.9347 \\
Organisational Culture & 3.56 & 0.6969 \\
\hline
\end{tabular}

Table 6 Job satisfaction dimensions average and standard deviations

\begin{tabular}{lcc}
\hline Dimensions & $\bar{x}$ & SS \\
\hline Wage & 3.27 & 0.6442 \\
Promotion & 3.20 & 0.607 \\
Management & 3.41 & 0.709 \\
Additional Payments & 3.21 & 0.5169 \\
Business Conditions & 3.27 & 0.612 \\
Job Itself & 4.03 & 0.8574 \\
Colleagues & 3.65 & 0.7511 \\
Communication & 2.99 & 0.6722 \\
Job Satisfaction & 3.38 & 0.4428 \\
\hline
\end{tabular}

value belonged to the "job itself" dimension $(x=4.03)$. It can be said that the job satisfaction of the participants was above average overall.

Correlation analysis is concerned with the degree of relationship between variables (Kurtuluş, 2004:p.317). Multiple correlation analysis is a type of relationship analysis aiming to identify the direction and extent of a (linear) relation between two or more predictive variables and a criterion variable (Kurtuluş, 2004:p.345). The correlation coefficient is a ratio, and its value varies between -1 and +1 . If the coefficient is positive, it means one of the variables increases as the other increases; and if the coefficient is negative, one of the variables increases as the other decreases (Nakip, 2003:p.322).

H1: There is a relationship between organisational culture and job satisfaction.

As shown in Table 7, there was a significant linear and positive correlation between organisational culture and job satisfaction at a level of $47.2 \%$, which corresponded to a medium strength. The hypothesis H1 was accepted based on the result of this correlation analysis. In this case, an increase in organisational culture will cause an increase in job satisfaction.

H2: There is a relationship between the dimensions of job satisfaction and the dimensions of organisational culture.

The relationships between the dimensions of job satisfaction and the dimensions of organisational culture are shown below. The dimensions of job satisfaction are as follows:

1. Wages,

2. Promotions,

3. Management,

4. Prerequisites,

5. Working conditions,

6. Job itself,

7. Colleagues, and

8. Communication.

Table 8 tests the hypothesis $\mathrm{H} 2$ of the study. As can be seen from the table, there were moderate linear and positive correlations between the dimensions of job satisfaction and the dimensions of organisational culture. There

Table 7 The relationship between organisational culture and job satisfaction

\begin{tabular}{ccc}
\hline & & Job Satisfaction \\
\hline \multirow{3}{*}{ Organisational Culture } & Pearson korelasyon & $0.472^{* *}$ \\
& Sig. (2-tailed) & 0.000 \\
& $N$ & 224 \\
\hline
\end{tabular}

** The correlation is significant at 0.01 level (2-way) 
Table 8 The relationship between the dimensions of organisational culture and the dimensions job satisfaction

\begin{tabular}{|c|c|c|c|c|c|c|c|c|c|}
\hline Organisational Culture & Job Satisfaction & 1 & 2 & 3 & 4 & 5 & 6 & 7 & 8 \\
\hline & Pearson Correlation & $0.216^{* *}$ & $0.215^{* *}$ & $0.327 * *$ & $0.301 * *$ & -0.058 & $0.237 * *$ & 0.008 & $0.163^{*}$ \\
\hline \multirow[t]{3}{*}{ Job Centred } & Sig. (2-tailed) & 0.008 & 0.008 & 0.000 & 0.000 & 0.482 & 0.004 & 0.925 & 0.047 \\
\hline & $N$ & 224 & 224 & 224 & 224 & 224 & 224 & 224 & 224 \\
\hline & Pearson Correlation & $0.335 * *$ & $0.292 * *$ & $0.347 * *$ & $0.219 * *$ & 0.128 & $0.496 * *$ & $0.167^{*}$ & $0.359 * *$ \\
\hline \multirow[t]{3}{*}{ Student Centred } & Sig. (2-tailed) & 0.000 & 0.000 & 0.000 & 0.007 & 0.118 & 0.000 & 0.041 & 0.000 \\
\hline & $N$ & 224 & 224 & 224 & 224 & 224 & 224 & 224 & 224 \\
\hline & Pearson Correlation & $0.178^{*}$ & $0.389 * *$ & $0.208^{*}$ & $0.276^{* *}$ & $0.161^{*}$ & $0.288 * *$ & $0.229 * *$ & $0.224 * *$ \\
\hline \multirow[t]{3}{*}{ Innovativeness } & Sig. (2-tailed) & 0.029 & 0.000 & 0.010 & 0.001 & 0.049 & 0.000 & 0.005 & 0.006 \\
\hline & $N$ & 224 & 224 & 224 & 224 & 224 & 224 & 224 & 224 \\
\hline & Pearson Correlation & $0.187^{*}$ & $0.288 * *$ & $0.299 * *$ & $0.213 * *$ & 0.008 & $0.362 * *$ & 0.115 & $0.255^{* *}$ \\
\hline \multirow[t]{3}{*}{ Management } & Sig. (2-tailed) & 0.022 & 0.000 & 0.000 & 0.009 & 0.922 & 0.000 & 0.162 & 0.002 \\
\hline & $N$ & 224 & 224 & 224 & 224 & 224 & 224 & 224 & 224 \\
\hline & Pearson Correlation & $0.258 * *$ & $0.314 * *$ & $0.343 * *$ & $0.247 * *$ & $0.196^{*}$ & $0.341 * *$ & 0.152 & $0.272 * *$ \\
\hline \multirow[t]{2}{*}{ Social Responsibility } & Sig. (2-tailed) & 0.001 & 0.000 & 0.000 & 0.002 & 0.016 & 0.000 & 0.063 & 0.001 \\
\hline & $N$ & 224 & 224 & 224 & 224 & 224 & 224 & 224 & 224 \\
\hline
\end{tabular}

** The correlation is significant at 0.01 level (2-way)

** The correlation is significant at 0.05 level (2-way)

were moderate significant correlations between the "communication" dimension of job satisfaction and the following dimensions of organisational culture: "Student centredness", "innovativeness", "systemic management control", and "social responsibility". There were strong correlations especially between the "job itself", "management", and "promotions" dimensions of job satisfaction and all dimensions of organisational culture. It was determined that there was overall a positive correlation between the dimensions of job satisfaction and the dimensions of organisational culture, and thus the hypothesis $\mathrm{H} 2$ was accepted.

\section{Discussions and conclusions}

In the increasingly competitive modern business world, the ability of businesses to maintain their continuity and to be ahead of their competitors is directly related to ensuring customer satisfaction. The concept of customer is now emerging as a comprehensive concept made up of internal customers and external customers by crossing traditional borders. A well-accepted general opinion is that it is not possible to achieve external customer satisfaction without the satisfaction of internal customers, i.e. business employees. This opinion is especially important for the service sector, where the product the service offers is human.

An examination of successful businesses shows that each has their own culture. Among the main reasons for their success is their ability to integrate the business and its employers within a framework of common goals and values, and thus to have a strong organisational culture.

A large portion of human life is work. In addition to gaining knowledge, skills and experience about the work throughout his or her professional life, an employee also develops experience in terms of his or her feelings such as happiness, sadness and anxiety at work. An employee's having positive attitudes about his or her job and workplace potentially improves his or her job satisfaction, and the improvement in his or her job satisfaction potentially improves performance and productivity at work. Personal and organisational consequences of job satisfaction play an essential role in setting the stage for achieving the objectives set by the organisation. Job satisfaction contributes to the development of physically and spiritually healthy and happy people in society.

In this study, an attempt was made to reveal the relationship between job satisfaction and the organisational culture of the employees of higher education institutions operating in Bishkek by analysing the data collected by using the questionnaire method. Based on the correlation analysis to identify the relationships between the variables, it was found that there were positive and significant correlations between the communication, job itself, management, promotion and prerequisites dimensions, which were the sub-dimensions of job satisfaction, and all the dimensions of organisational culture. Positive correlations 
emerged between the student centredness and social responsibility dimensions of organisational culture and the wages dimension of job satisfaction.

In this study, it was concluded that the level of organisational culture of the employees of the higher education institutions was above the value (3.00), which was determined to be moderate. In Kyrgyzstan, an appreciation of the importance of organisational culture for institutions is only newly emerging. At the time of the study, neither managers nor employees paid as much attention to the organisational culture of the institution where they worked as it arguably deserved. Similarly, the level of job satisfaction of the participants was found to be above the value (3.00). Academics are partly satisfied with their jobs.

An examination of the literature shows that the general belief regarding organisational culture is that a strong organisational culture in institutions is considered to be a good thing. This is because a strong organisational culture plays a decisive role in an organisation's effectiveness. However, a strong organisational culture can become a structure that creates stagnation and resists changes, preventing changes that are necessary for the organisation from being carried out. Therefore, modern institutions need a strong organisational culture that empowers employees, has a highly innovative and flexible structure, and has basic values that can be perpetually renewed and improved.

Based on the results of this study, it can be said that possession of a strong organisational culture has to be one of the main goals of educational institutions. In this context, the following recommendations can be made to foster a strong organisational culture in higher education institutions:

- Institutions can develop and implement a certain number of harmonised HR policies.

- Recruitment of personnel who are believed to be fit for the institutional culture is recommended.

- It is recommended that institutions implement training and adaptation programmes during staff onboarding, and monitor the outcomes of such programmes.

- The opinions and ideas of employees should be recognised, and employees should be given the opportunity to express their ideas and opinions freely. Opinions and ideas put forward should be considered in a timely manner.

- It may be advisable for managers to be sensitive to employees and to care about the personal development of employees.

- Meetings should be held, and joint decisions should be taken to establish the organisational culture.
The system must be installed and it should not be modified by one person.

- In order to develop the organisational culture, emphasis should be placed on the written culture.

To increase job satisfaction based on the results mentioned above, the following may be recommended:

- Educational institutions should explicitly outline their institutional identity and determine their vision, mission, strategies and corporate policies. This is because transparency is one of the factors that ensure job satisfaction. In this way, employees can collaborate consciously and willingly to achieve common goals.

- Human resources managers should use business analysis, business justification and business evaluation forms effectively when searching for and choosing employees. In this way, it may be possible to prevent problems related to the lack of adaptation of a person to the work.

- Universities should offer opportunities that are needed for the training and development of their employees. This makes it possible to share in-house experiences and skills, and it will be easy to adapt to changing environmental conditions.

- Managers should administer questionnaires to employees at certain intervals to identify the desires of employees and the faulty aspects of the organisation. In this way, the problems of the employees are solved in a short period of time and job satisfaction is improved.

- Certain management decisions can be made to improve employee centredness.

- More heed should be paid to use promotions, prerequisites and specific rights in accordance with the needs of employees and fairly.

- It may be advisable for human resources and management to be open to innovation and change, but these innovations and changes should be kept under the control of management.

Today, higher education institutions need to have a good relationship with their employees, who are their internal customers, in order to ensure competitive advantage by satisfying the needs of their stakeholders. Employees' having a high level of satisfaction improves overall organisational performance. Employees who are unsatisfied with the work they are doing exhibit behaviours such as absenteeism, being late, and ultimately quitting their jobs. 
This prevents the development of an organisational culture. It causes the new members of the organisation to have bad thoughts about the organisation. With all these in mind, it is necessary to emphasise that job satisfaction and organisational culture are crucial for university institutions.

\section{References}

Akıncı, Z. (2002) "Turizm Sektöründe İşgören İş Tatminini Etkileyen Faktörler: Beş Yıldızlı Konaklama İşletmelerinde Bir Uygulama" (Factors which Affect Job Satisfaction in the Tourism Sector: A Survey in Five Star Hospitality Organizations), Akdeniz İ.İ.B.F. Dergisi, 4, pp. 1-25. (in Turkish)

Akşit Aşık, N. (2010) "Çalışanların İş Doyumunu Etkileyen Bireysel ve Örgütsel Faktörler İle Sonuçlarına İlişkin Kavramsal Bir Değerlendirme" (A Conceptual Evaluation of Individual and Organizational Factors Affecting Employees' Job Satisfaction and their Results), Türk İdare Dergisi, 82(467), pp. 31-51. (in Turkish)

Barutçu, E., Serinkan, C. (2012) "Yöneticilerin Liderlik Davranışları ve Örgüt Kültürü Arasındaki İlişki: Denizli İşletmelerinde Bir Uygulama" (The Relationship between the Managerial Leadership Behaviors and Organizational Culture: A Study in Denizli Enterprises), In: 11. Ulusal İşletmecilik Kongresi, Konya, Turkey, pp. 844-850. (in Turkish)

Bayrak Kök, S. (2006) "İş Tatmini ve Örgütsel Bağlılı̆̆ın İncelenmesine Yönelik Bir Araştırma" (A Research on Job Satisfaction and Organizational Commitment), Atatürk University Journal of Economics and Administrative Sciences, 20(1), pp. 291-317. (in Turkish)

Blake, R., Mouton, J. (1964) "The Managerial Grid: The Key to Leadership Excellence", Gulf Publishing Co., Houston, TX, USA.

Büyüköztürk, Ş. (2002) "Factor Analysis: Basic Concepts and Using the Development Scales", Educational Administration: Theory and Practice, 32(32), pp. 470-483.

Cameron, K. S., Quinn, R. E. (2005) "Diagnosing and Changing Organizational Culture", Jossey Bass, San Francisco, CA, USA.

Çetin, F. (2011) "Örgütsel Vatandaşlık Davranışlarının Açıklanmasında Örgütsel Bağlılık, İş Tatmini, Kişilik ve Örgüt Kültürünün Rolü" (The Role of Organizational Commitment, Job Satisfaction, Personality and Organizational Culture in Explaining Organizational Citizenship Behaviors), Ankara University Graduate School of Social Sciences, Unpublished PhD Thesis.

Deal, T. E., Kennedy, A. A. (2000) "Corporate cultures: The rites and rituals of corporate life", Perseus Publishing, Cambridge, MA, USA.

Demirkol, A. Y., Savaş, A. C. (2012) "Okul Müdürlerinin Örgüt Kültürü Alg1larının İncelenmesi" (An Investigation on the Perceptions of School Principals about the Organizational Culture), SDU Faculty of Arts and Sciences Journal of Social Sciences, 25, pp. 259-272. (in Turkish)

Denison, D. R. (1990) "Corporate Culture and Organizational Effectiveness", John Wiley \& Sons, New York, NY, USA.

Hakim, M. A. (2015) "Organizational Culture and Job Satisfaction in Bank: Perceptions and Reactions of Employees", Global Disclosure of Economics and Business, 4(2), pp. 167-180.

Handsome, J. D. (2009) "The Relationship between Leadership Style and Job Satisfaction", PhD Thesis, Walden University.
Researchers who would like to conduct studies in this field may be advised to increase the number people in the sample and, if possible, to use a stratified sampling method in order to obtain information that is even broader and that can be generalised to the wider education sector.

Harrison, J. R., Carroll, G. R. (2006) "Culture and Demography in Organizations", Princeton University Press, Princeton, NJ, USA.

Hofstede, G., Hofstede, G. J., Minkov, M. (2010) "Cultures and Organizations: Software of the Mind", McGraw-Hill, New York, NY, USA.

National Statistical Committee of the Kyrgyz Republic "5.03.01.03 Number of educational institutions by types, patterns of ownership and territory", [online] Available at: http://www.stat.kg/media/ statisticsdynamic/62f442e4-c5d1-4ee3-943d-9b7b3cd83c15.x1s [Accessed: 10 February 2017]

İşcan, Ö. F., Timuroğlu, M. K. (2007) "Örgüt Kültürünün İş Tatmini Üzerindeki Etkisi ve Bir Uygulama" (The Effect of Organizational Culture on Job Satisfaction: An Application), Atatürk Üniversitesi İktisadi ve İdari Bilimler Dergisi, 21(1), pp. 119-135. (in Turkish)

Johnson, J. J., McIntye, C. L. (1998) "Organizational Culture and Climate Correlates of Job Satisfaction", Psychological Reports, 82(3), pp. 843-850. https://doi.org/10.2466/pr0.1998.82.3.843

Kurtuluş, K. (2004) "Pazarlama Araştırmaları" (Marketing Research), Literatür Yayıncılık, Istanbul, Turkey. (in Turkish)

Loi, R., Yang, J., Diefendorff, J. (2009) "Four-Factor Justice and Daily Job Satisfaction: A Multilevel Investigation", Journal of Applied Psychology, 94(3), pp. 770-781. https://doi.org/10.1037/a0015714

Luthans, F. (1995) "Organizational Behavior", McGraw-Hill Inc., New York, NY, USA.

Morgan, G. (2006) "Images of Organization", Sage Publications, Inc., Thousand Oaks, CA, USA.

Mullins, L. J. (2010) "Management and Organizational Behaviour", Financial Times Prentice Hall, Harlow, UK.

Nakip, M. (2003) "Pazarlama Araştırmaları: Teknikler ve (SPSS Destekli) Uygulamalar" (Marketing Research Techniques and (SPSS Supported) Applications), Seçkin Yayıncılık, Ankara, Turkey. (in Turkish)

Nystrom, P. C. (1993) "Organizational cultures, strategies, and commitment in health care organizations", Health Care Management Review, 18(1), pp. 43-49.

Odom, R, Y., Boxx, W. R., Dunn, M. G. (1990) "Organizational Cultures, Commitment, Satisfaction, and Cohesion", Public Productivity \& Management Review, 14(2), pp. 157-169.

Özden, K., Najimudinova, S. (2013) "Örgüt Kültürü Görsel Öğelerinin Örgüt Çalışanları Tarafından Algılanması: Bişkek Örneği" (The Perception of Employees on Visual Elements of Organizational Culture: In the Case of Bishkek), Journal of Yasar University, 29(8), pp. 4813-4834. (in Turkish)

Pettigrew, A. M. (1979) "On Studying Organizational Cultures", Administrative Science Quarterly, 24(4), pp. 570-581.

https://doi.org/10.2307/2392363 
Querstein, V. A., McAffe, R. B., Glassman, M. (1992) "The Situational Occurrences Theory of Job Satisfaction", Human Relations, 45(8), pp. $859-873$.

https://doi.org/10.1177/001872679204500806

Rosenthal, J., Masarech, M. A. (2003) "High-Performance Cultures: How Values Can Drive Business Results", Journal of Organizational Excellence, 22(2), pp. 3-18. https://oi.org/10.1002/npr.10062

Robbins, S. P. (1986) "Organizational Behavior", Prentice Hall, Englewood Cliffs, NJ, USA.

Robbins, S. P., Judge, T. A. (2013) "Örgütsel Davranış" (Organizational Behavior), (Translated by Erdem, İ. (ed.)), Nobel Yayın Dağıtım, Ankara, Turkey. (in Turkish)

Sabuncuoğlu, Z., Tüz, M. V. (2005) "Örgütsel Psikoloji" (Organizational Psychology), Alfa Yayınları, Bursa, Turkey. (in Turkish)

Schein, E. H. (1990) "Organizational Culture", American Psychologist, 45(2), pp. 109-119. https://doi.org/10.1037/0003-066X.45.2.109

Schulte, M., Ostroff, C., Shmulyian, S., Knicki, A. (2009) "Organizational Climate Configurations: Relationships to Collective Attitudes, Customer Satisfaction and Financial Performane", Journal of Applied Psychology, 94(3), pp. 618-634. https://doi.org/10.1037/a0014365

Spector, P. E. (1997) "Job Satisfaction. Application, Assessment, Causes, and Consequences", Sage Publications, Inc., Thousand Oaks, CA, USA.

https://doi.org/10.4135/9781452231549

Tanner, B. M. (2007) "An Analysis of the Relationships among Job Satisfaction, Organizational Trust, and Organizational Commitment in an Acute Care Hospital", PhD Thesis, Saybrook Graduate School and Research Center.

Tella, A., Ayeni, C. O., Popoola, S. O. (2007) "Work Motivation, Job Satisfaction, and Organisational Commitment of Library Personnel in Academic and Research Libraries in Oyo State, Nigeria", Library Philosophy and Practice, Article number: 118.
Toker, B. (2007) "Demografik Değişkenlerin İş Tatminine Etkileri: İzmir'deki Beş ve Dört Yıldızlı Otellere Yönelik Bir Uygulama" (The Effects of Demographic Factors on Job Satisfaction: An Application on Five and Four Star Hotels in Izmir), Doğuş Üniversitesi Dergisi, 8(1), pp. 92-107. (in Turkish) https://doi.org/10.31671/dogus.2019.245

Trevino, L. K., Nelson, K. A. (1999) "Managing Business Ethics: Straight Talk about How to Do It Right", John Wiley \& Sons, Inc., New York, NY, USA.

Tsai, Y. (2011) "Relationship between Organizational Culture, Leadership Behavior and Job Satisfaction", BMC Health Services Research, 11, Article number: 98. https://doi.org/10.1186/1472-6963-11-98

Tsui, A. S., Zhang, Z., Wang, H., Xin, K. R., Wu, J. B. (2006) "Unpacking the relationship between CEO leadership behavior and organizational culture", The Leadership Quarterly, 17(2), pp. 113-137. https://doi.org/10.1016/j.leaqua.2005.12.001

Türk, M. S. (2007) "Örgüt Kültürü ve İş Tatmini" (Organizational Culture and Job Satisfaction), Özkan Matbaacılık, Ankara, Turkey. (in Turkish)

Udechukwu, I. I. (2007) "The Influence of Intrinsic and Extrinsic Satisfaction on Organizational Exit (Voluntary Turnover): Evidence from a Correctional Setting", The Journal of Applied Management and Entrepreneurship, 12(1), pp. 127-141.

Unutkan, G. A. (1995) "İşletmelerin Yönetimi ve Örgüt Kültürü" (Business Management and Organizational Culture), Türkmen Kitabevi, Istanbul, Turkey. (in Turkish)

Wagner, J. A., Hollenbeck, J. R. (2010) "Organizational Behavior: Securing Competitive Advantage", Routledge, New York, NY, USA.

Yelboğa, A. (2009) "Validity and Reliability of the Turkish Version of the Job Satisfaction Survey (JSS)", World Applied Sciences Journal, 6(8), pp. 1066-1072. 